\title{
Electronic absorption spectra of palladium(II) in concentrated nitric acid solutions
}

\section{$\operatorname{AUTHOR}(\mathrm{S})$ :}

Fujii, Toshiyuki; Egusa, Souichirou; Uehara, Akihiro; Kirishima, Akira; Yamagishi, Isao; Morita, Yasuji; Yamana, Hajimu

\section{CITATION:}

Fujii, Toshiyuki ...[et al]. Electronic absorption spectra of palladium(II) in concentrated nitric acid solutions. Journal of Radioanalytical and Nuclear Chemistry 2011, 290(2): 475478

\section{ISSUE DATE:}

2011-11

URL:

http://hdl.handle.net/2433/151093

\section{RIGHT:}

The final publication is available at www.springerlink.com; This is not the published version. Please cite only the published version.; この論文 は出版社版でありません。引用の際には出版社版をご確認ご利用くだ さい。 
Short Communication

Electronic absorption spectra of palladium(II) in concentrated nitric acid solutions

Toshiyuki Fujii, ${ }^{1}$ Souichirou Egusa, ${ }^{1,2}$ Akihiro Uehara, ${ }^{1}$ Akira Kirishima, ${ }^{3}$ Isao Yamagishi, ${ }^{4}$ Yasuji Morita, ${ }^{4}$ and Hajimu Yamana ${ }^{1}$

1 Division of Nuclear Engineering Science, Research Reactor Institute, Kyoto University, 2-1010, Asashiro Nishi, Kumatori, Sennan, Osaka, 590-0494, Japan

2 Graduate School of Engineering, Kyoto University, Kyoto daigaku-Katsura, Nishikyo-ku, Kyoto 615-8530, Japan

${ }^{3}$ Institute of Multidisciplinary Research for Advanced Materials, Tohoku University, Katahira 2-1-1, Aoba, Sendai 980-8577, Japan

4 Nuclear Science and Engineering Directorate, Japan Atomic Energy Agency, Tokai-mura, Ibaraki-ken 319-1195, Japan

*Author to whom correspondence should be addressed tosiyuki@rri.kyoto-u.ac.jp TEL: +81-724-51-2469, FAX: +81-724-51-2634

E-mail: tosiyuki@rri.kyoto-u.ac.jp 


\begin{abstract}
Palladium complexation in concentrated nitric acid solutions was studied by UV/Vis absorption spectrophotometry. The ionic strength of the solutions was fixed to $I=1,3$, or $5 \mathrm{~mol} \mathrm{dm}{ }^{-3}(\mathrm{M})$ by mixing of $\mathrm{HNO}_{3}$ and $\mathrm{HClO}_{4}$. The major palladium species were found to be $\mathrm{Pd}^{2+}, \mathrm{PdNO}_{3}{ }^{+}$, and $\mathrm{Pd}\left(\mathrm{NO}_{3}\right)_{2}$. The formation constant of $\mathrm{PdNO}_{3}{ }^{+}$was determined to be $\beta_{1}=1.32(I=1 \mathrm{M}), 1.49(I=3 \mathrm{M})$, or $1.47(I=5 \mathrm{M})$, while that of $\operatorname{Pd}\left(\mathrm{NO}_{3}\right)_{2}$ to be $\beta_{2}=0.45(I=3 \mathrm{M})$ or $0.14(I=5 \mathrm{M})$.
\end{abstract}

Keywords

Palladium $\cdot$ Nitric acid $\cdot$ Absorption spectrophotometry $\cdot$ Ionic strength $\cdot$ Formation constant 


\section{Introduction}

Molybdenum (Mo), technetium $(\mathrm{Tc})$, ruthenium $(\mathrm{Ru})$, rhodium $(\mathrm{Rh})$, and palladium $(\mathrm{Pd})$ are known as the noble metal fission product (NMFP) elements in reprocessing of spent nuclear fuels. In the vitrification process, since the solubility of NMFPs to glass materials is very low, their existence sometimes leads to an inhomogeneity of the vitrified waste. Separating NMFPs from the high radioactive liquid waste (HAW) in advance may be preferable to avoid degrading the vitrified waste. Solvent extraction is a promised technique to separate NMFPs from HAW, but the complicated chemical behavior of these elements in nitric acid solutions is problematic. The reliable complexation data of NM nitrates in $\mathrm{HNO}_{3}$ are essential.

There are only a few literatures [1-4] that report the formation constants of Pd nitrates. These are widely dispersed, e.g., the formation constant of $\mathrm{PdNO}_{3}{ }^{+}\left(\beta_{1}\right)$ reported is ranged from 1.2 [1] to 14 [3]. The $\beta$ values have been determined by solvent extraction technique [3] and absorption spectrophotometry [1,4]. The higher $\beta$ values, that is, $\beta_{3}$ for $\mathrm{Pd}\left(\mathrm{NO}_{3}\right)_{3}{ }^{-}$and $\beta_{4}$ for $\mathrm{Pd}\left(\mathrm{NO}_{3}\right)_{4}{ }^{2-}$, were determined in solvent extractions [3], while the latter analysis was applied for only $\beta_{1}$ and $\beta_{2}, \operatorname{Pd}\left(\mathrm{NO}_{3}\right)_{2}[1,4]$. The solvent extraction technique has a difficulty to keep the constant ionic strength due to the extraction of acid and/or solutes of buffer solutions. The activity coefficient of extracted species in organic phase is also difficult to know. The absorption spectrophotometry is free from these difficulties.

Palladium complexes generally have the square-planar structure via the hybrid orbital $d s p^{2}$. This means that $\mathrm{Pd}^{2+}$ has four coordination sites. An XAFS (x-ray absorption fine structure) study [5] suggests that $1-2 \mathrm{NO}_{3}{ }^{-}$ions coordinate to $\mathrm{Pd}^{2+}$ at $\sim 3$ 
mol dm $\mathrm{dm}^{-3}(\mathrm{M}) \mathrm{HNO}_{3}$, which is a typical acidity of the aqueous reprocessing of spent nuclear fuels. The formation constants $\beta_{1}$ and $\beta_{2}$ are therefore most important. In the present study, $\beta_{1}$ and $\beta_{2}$ were determined for ionic strength 1,3 , and $5 \mathrm{M}$ by UV/Vis absorption spectrophotometry.

\section{Experimental}

Because of the formation of $\mathrm{Pd}$ oxide and hydroxide [6], preparing nitric acid solutions of $\mathrm{Pd}(\mathrm{II})$ from $\mathrm{Pd}(\mathrm{OH})_{2}$ or hydrated $\mathrm{Pd}\left(\mathrm{NO}_{3}\right)_{2}$ was not applied in the present study. The most reliable preparation method is dissolving Pd metal by boiling $\mathrm{HNO}_{3}$ [1]. $1.6 \mathrm{mg}$ of Pd metal with $0.1 \mu \mathrm{m}$ grain size (Nilaco Co., 99.5\% purity) was dissolved in boiling 190 $\mathrm{mL}$ of $13.3 \mathrm{M} \mathrm{HNO}_{3}$. After the complete dissolution, the solution was continuously heated for 6 hours to destroy an unidentified source of $\mathrm{NO}_{2}$, and then the solution was cooled down. The solution was filtered by a Nuclepore track-etched polycarbonate membrane with $0.015 \mu \mathrm{m}$ pore size. The concentration of $\mathrm{Pd}(\mathrm{II})$ was determined by ICP-QMS (Yokogawa, HP-4500) and $\left[\mathrm{HNO}_{3}\right]$ by neutralization titration with $\mathrm{NaOH}$. This solution of $0.088 \mathrm{M} \mathrm{Pd}$ in $13.3 \mathrm{M} \mathrm{HNO}_{3}$ was used as the starting material.

The starting material was diluted by $\mathrm{HNO}_{3}$ and $\mathrm{HClO}_{4}$ to prepare sample solutions with various $\left[\mathrm{NO}_{3}{ }^{-}\right]$at ionic strength $I=1,3$, and $5 \mathrm{M}$. The sample was transferred in a quartz cell with $10 \mathrm{~mm}$ light path length. A Pd free reference solution with the same acid condition was also prepared. In order to decrease uncertainty of volumetric treatment, all sample solutions were prepared gravimetrically. Volumetric concentration was calculated from weight and density of solution. The absorption spectrum was measured by using an UV/Vis/NIR spectrophotometer (JASCO, V-7200) 
at room temperature. The absorbance was measured in the wavelength range of 350-600 $\mathrm{nm}$ at $1 \mathrm{~nm}$ intervals.

\section{Results and discussion}

The electronic absorption spectra obtained are shown in Fig. 1. The absorption band of $d$-d transitions is clearly seen at $400 \mathrm{~nm}$. The energy levels of the $d-d$ transition have been investigated in detail for Pd(II) halides [7]. In a pioneering spectroscopic study on $\mathrm{Pd}(\mathrm{II})$ in acid solutions, addition of $\mathrm{HNO}_{3}$ in a $\mathrm{Pd}(\mathrm{II}) / \mathrm{HClO}_{4}$ solution has been tested [8]. The absorbance of the $d$ - $d$ transition band was found to increase with $\left[\mathrm{HNO}_{3}\right]$, in which the absorption maximum shifted to longer wavelength. The same absorption characteristics are found in our results. The shift of the absorption maximum suggests the complexation of $\mathrm{Pd}(\mathrm{II})$ nitrate, $\mathrm{Pd}\left(\mathrm{NO}_{3}\right)^{+}$. The spectrum shape changed at high acidity region, e.g., at $5 \mathrm{M} \mathrm{HNO}_{3}$ shown in Fig. 1c. This may be due to a higher complexation of $\mathrm{Pd}(\mathrm{II})$ nitrate as $\mathrm{Pd}\left(\mathrm{NO}_{3}\right)_{2}$. In the present paper, $\mathrm{Pd}^{2+}, \mathrm{Pd}\left(\mathrm{NO}_{3}\right)^{+}$, and $\operatorname{Pd}\left(\mathrm{NO}_{3}\right)_{2}$ were considered as major species under our experimental conditions. For $\operatorname{Pd}\left(\mathrm{NO}_{3}\right)_{n}{ }^{2-n}(n=0,1$, or 2$)$, the complexation reaction and its formation constant (apparent) are,

$$
\begin{aligned}
& \mathrm{Pd}^{2+}+n \mathrm{NO}_{3}{ }^{-} \rightleftarrows \mathrm{Pd}\left(\mathrm{NO}_{3}\right)_{n}{ }^{2-n} \\
& \beta_{n}=\frac{\left[\mathrm{Pd}\left(\mathrm{NO}_{3}\right)_{n}{ }^{2-n}\right]}{\left[\mathrm{Pd}^{2+}\right]\left[\mathrm{NO}_{3}\right]^{-}}
\end{aligned}
$$

The absorbance at a wavelength $\lambda, A(\lambda)$, observed is the product of $\varepsilon(\lambda)$ shown in Fig. 1 
and total concentration of $\mathrm{Pd}(\mathrm{II})$ in solutions,

$$
\begin{aligned}
& A(\lambda)=\varepsilon(\lambda)[\mathrm{Pd}(\mathrm{II})] \\
& =\sum_{n=0}^{2} \varepsilon_{n}(\lambda)\left[\mathrm{Pd}\left(\mathrm{NO}_{3}\right)_{n}{ }^{2-n}\right]
\end{aligned}
$$

where $\varepsilon_{n}(\lambda)$ means the molar absorptivity of $\mathrm{Pd}\left(\mathrm{NO}_{3}\right)_{n}{ }^{2-n}$ at $\lambda$. From Eqs. (2) and (3), $\varepsilon(\lambda)$ obtained in the present study is shown as,

$$
\varepsilon(\lambda)=\frac{\varepsilon_{0}(\lambda)+\varepsilon_{1}(\lambda) \beta_{1}\left[\mathrm{NO}_{3}^{-}\right]+\varepsilon_{2}(\lambda) \beta_{2}\left[\mathrm{NO}_{3}^{-}\right]^{2}}{1+\beta_{1}\left[\mathrm{NO}_{3}^{-}\right]+\beta_{2}\left[\mathrm{NO}_{3}^{-}\right]^{2}}
$$

Dependence of $\varepsilon(\lambda)$ on $\left[\mathrm{HNO}_{3}\right]$ for $\lambda=400,450$, and $500 \mathrm{~nm}$ at $I=3 \mathrm{M}$ is shown in Fig. 2 as an example. $\left[\mathrm{HNO}_{3}\right]$ is approximated to be $\left[\mathrm{NO}_{3}{ }^{-}\right]$in this study. At each wavelength, $\varepsilon(\lambda)$ vs $\left[\mathrm{HNO}_{3}\right]$ shows a function expressed as Eq. 4. Since spectra shown in Fig. 1 were measured in wavelength range from 350 to $600 \mathrm{~nm}$ at $1 \mathrm{~nm}$ intervals, 251 curves for different 251 wavelengths like Fig. 2 can be obtained for $I=1,3$, or $5 \mathrm{M}$. This means that 251 sets of $\varepsilon_{0}(\lambda), \varepsilon_{1}(\lambda), \varepsilon_{2}(\lambda), \beta_{1}$, and $\beta_{2}$ are obtained, in which $\beta_{1}$ and $\beta_{2}$ are constants. This multiple analysis was performed by employing a computational program, HypSpec [9]. The calculation results are shown in Table 1. The literature data are shown together.

It has been suggested that the Pd nitrates are markedly dissociated at low nitrate concentrations [8]. This means the small formation constants of the Pd nitrates. The $\beta$ values obtained by absorption spectrophotometry showed similar values. The magnitude of the $\mathrm{PdNO}_{3}{ }^{+}$formation constant is $\log \beta_{1}<0.18$, which is much smaller 
than that of $\mathrm{Pd}$ halides, e.g., $\log \beta_{1}{ }^{\mathrm{o}}$ for $\mathrm{PdCl}^{+}$at ionic strength $I=0 \mathrm{M}$ is reported to be 5.08 [10]. The $\beta_{1}$ values determined by absorption spectrophotometry listed in Table 1 are shown in Fig. 3 as a function of ionic strength in molality unit $(\mathrm{mol} / \mathrm{kg})$. From the specific ion interaction theory (SIT) (see a review [11]), the following formula is given for Eq. 1 with $n=1$,

$$
\log \beta_{1}+4 D=\log \beta_{1}{ }^{\mathrm{o}}-\Delta \varepsilon I
$$

where $\Delta \varepsilon$ is the ionic strength dependence of ion interaction coefficient and $D$ the Debye-Hückel term,

$$
D=\frac{0.5091 \sqrt{I}}{1+1.5 \sqrt{I}}
$$

The constants 0.5091 and 1.5 were found to minimize $\Delta \varepsilon$ at $I=0.5-3.5 \mathrm{~mol} / \mathrm{kg}$. A straight line shown in Fig. 3 was fitted for two our data and that of [1] at $I \leq 3.5 \mathrm{~mol} / \mathrm{kg}$ considering experimental uncertainties. Though it is a rough SIT correction, $\log \beta_{1}{ }^{\mathrm{o}}=$ 0.84 and $\Delta \varepsilon=0.01 \mathrm{~kg} / \mathrm{mol}$ were determined. Pd(II) has a large hydrolysis constant [12], from which $\sim 0.5 \%$ of $\mathrm{Pd}(\mathrm{II})$ is estimated to form $\mathrm{Pd}(\mathrm{OH})^{+}$even in high acidic region of $\left[\mathrm{H}^{+}\right]=1 \mathrm{M}$. Because of the strong hydrolysis and weak association with $\mathrm{NO}_{3}{ }^{-}$, the SIT correction for Pd nitrates must be performed in a lack of data at low acidity.

As shown in Fig. 3, $\beta_{1}$ at high acidity $\sim 5 \mathrm{M} \mathrm{HNO}_{3}$ was not ruled by the SIT correction of cation-anion interactions. This may be due to the cation-cation, anion-anion, or higher interactions taken place in concentrated electrolytes. The $\beta_{2}$ value 
was determined only at high acidity. Though our data at $5 \mathrm{M}$ agreed with the literature data [4], it is out of the SIT correction region.

In order to clarify the separation performance of Pd from HAW solutions, solvent extraction behavior of $\mathrm{Pd}$ from $\mathrm{HNO}_{3}$ solutions with various extractants has been studied $[2,3,13,14]$. Since the complex formation constant of Pd-extractant is evaluated from distribution ratios of $\mathrm{Pd}$ and $\beta$ values of $\mathrm{Pd}$ nitrates, accurate $\beta$ values covering wide $\left[\mathrm{HNO}_{3}\right]$ region are required. Our data covering 1-5 $\mathrm{M} \mathrm{HNO}_{3}$ region are hence useful for this purpose.

\section{Conclusions}

The formation constant of $\mathrm{PdNO}_{3}{ }^{+}$in $\mathrm{HNO}_{3}-\mathrm{HClO}_{4}$ mixtures was determined to be $\beta_{1}=$ $1.32(I=1 \mathrm{M}), 1.49(I=3 \mathrm{M})$, or $1.47(I=5 \mathrm{M})$, while that of $\operatorname{Pd}\left(\mathrm{NO}_{3}\right)_{2}$ to be $\beta_{2}=0.45$ $(I=3 \mathrm{M})$ or $0.14(I=5 \mathrm{M})$. The $\beta$ values agreed with the literature values determined by absorption spectrophotometry. The obtained data covering 1-5 $\mathrm{M} \mathrm{HNO}_{3}$ region are useful for the aqueous reprocessing process of spent nuclear fuels.

\section{Acknowledgment}

A part of this study is the result of "Development of High-level Liquid Waste Conditioning Technology for Advanced Nuclear Fuel Cycle" entrusted to "Japan Atomic Energy Agency" by the Ministry of Education, Culture, Sports, Science and Technology of Japan (MEXT).

\section{References}

[1] Jørgensen CK, Parthasarathy V (1978) Acta Chem Scand A32:957 
[2] Tarapčik P (1981) Radiochem Radioanal Lett 49:353

[3] Shmidt VS, Mezhov ÉA, Rubisov VN, Troyanovskii LV, Shorokhov NA (1985)

Radiochem 28:311

[4] Frias EC, Pitsch HK, Ly J, Poitrenaud C (1995) Talanta 42:1675

[5] Purans J, Fourest B, Cannes C, Sladkov V, David F, Venault L, Lecomte M (2005) J Phys Chem B 109:11074

[6] Venediktov AB, Korenev SV, Khranenko SP, Tkachev SV, Plyusnin PE, Mamonov SN, Ivanova LV, Vostrikov VA (2007) Russ J Appl Chem 80:695

[7] Elding LI, Olsson LF (1978) J Phys Chem 82:69

[8] Sundaram AK, Sandell EB (1955) J Am Chem Soc 77:855

[9] Gans P, Sabatini A, Vacca A (1996) Talanta 43:1739

[10] Kragten J (1980) Talanta 27:375

[11] Guillaumont R, Fanghänel T, Fuger J, Grenthe I, Neck V, Palmer DA, Rand MH, Update on the Chemical Thermodynamics of Uranium, Neptunium, Plutonium, Americium and Technetium, Elsevier, Amsterdam, 2003

[12] Nabivanets BI, Kalabina LV (1970) Russ J Inorg Chem 15:818

[13] Fujii T, Yamana H, Watanabe M, Moriyama H (2001) J Radioanal Nucl Chem $247: 435$

[14] Dakshinamoorthy A, Venugopal V (2005) J Radioanal Nucl Chem 425:429 
Table 1 Stability constants of palladium nitrates.

\begin{tabular}{|c|c|c|c|c|}
\hline Method & $I[\mathrm{M}]$ & $\beta_{1}$ & $\beta_{2}$ & Reference \\
\hline Absorption spectrophotometry & $2.0-2.1$ & $1.2 \pm 0.4$ & - & [1] \\
\hline Spectrophotometry $^{a}$ & $0.95-3.04^{a}$ & 3.28 & 2.13 & [2] \\
\hline Solvent extraction & $0.25-2.0$ & 14 & 2 & [3] \\
\hline Absorption spectrophotometry & 5.18 & $1.47 \pm 0.08$ & $0.173 \pm 0.015$ & [4] \\
\hline Absorption spectrophotometry & 1.0 & $1.32 \pm 0.02^{b}$ & - & This study \\
\hline Absorption spectrophotometry & 3.0 & $1.49 \pm 0.04^{b}$ & $0.45 \pm 0.06^{b}$ & This study \\
\hline Absorption spectrophotometry & 5.0 & $1.47 \pm 0.03^{b}$ & $0.14 \pm 0.06^{b}$ & This study \\
\hline
\end{tabular}




\section{Figure captions}

Fig. 1 Electronic absorption spectra of $\mathrm{Pd}(\mathrm{II})$ in $\mathrm{HNO}_{3}-\mathrm{HClO}_{4}$ mixtures. Ionic strength was set to be 1,3 , or $5 \mathrm{M}$. a $I=1 \mathrm{M}$. b $I=3 \mathrm{M}$. c $I=5 \mathrm{M}$

Fig. 2 Molar absorptivities of $\mathrm{Pd}(\mathrm{II})$ at 400, 450, and $500 \mathrm{~nm}$ wavelength. The solutions were the mixtures of $\mathrm{HNO}_{3}-\mathrm{HClO}_{4}$ with ionic strength $I=3 \mathrm{M}$

Fig. $3 \log \beta_{1}+4 D$ vs $I$ 

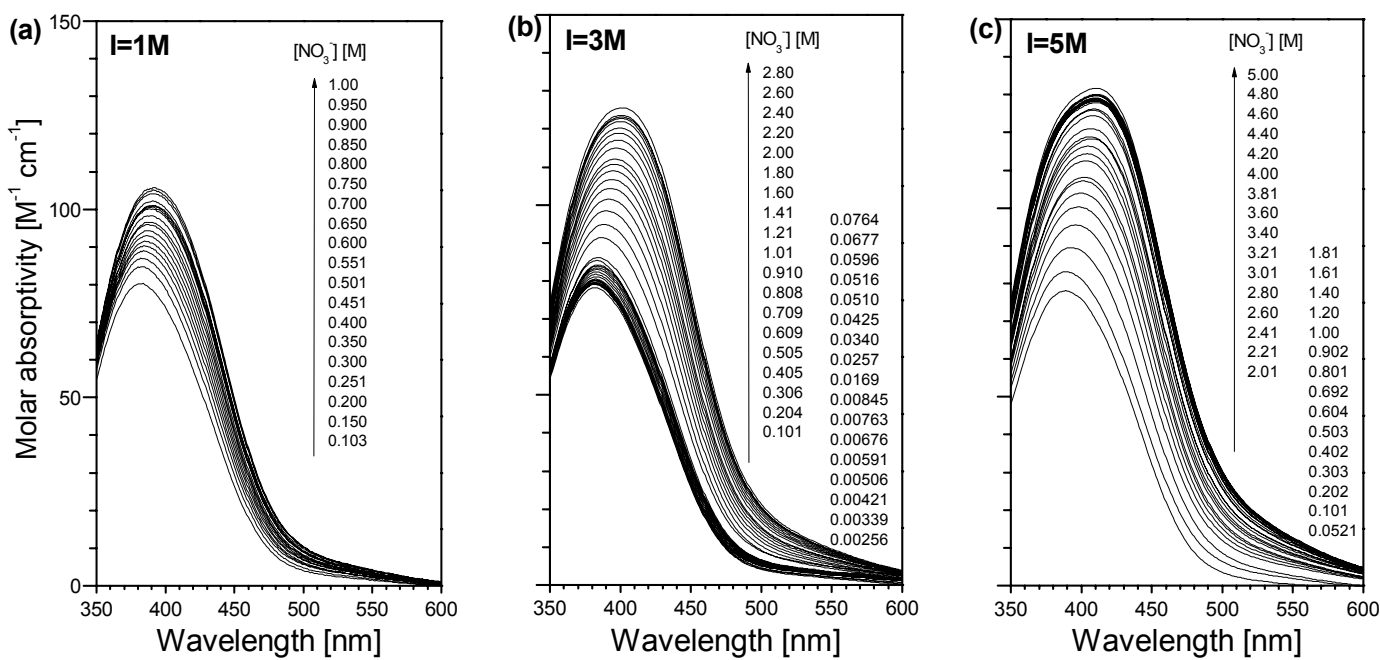

Figure 1 (Fujii et al.) 


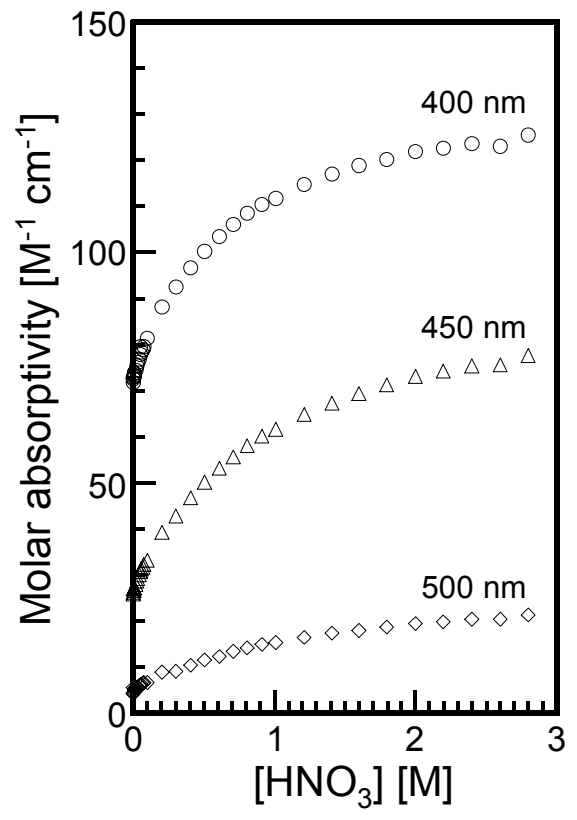

Figure 2 (Fujii et al.) 


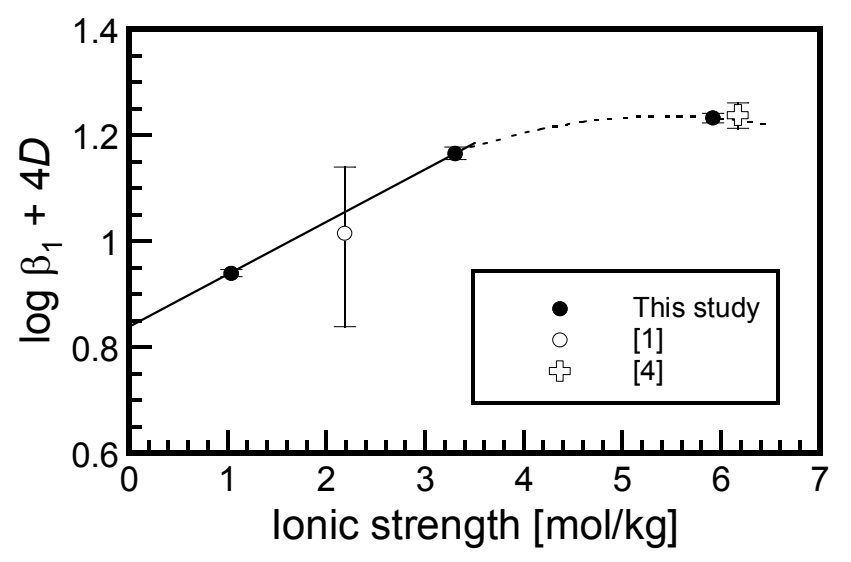

Figure 3 (Fujii et al.) 